\title{
Assessing Vulnerability of Maasai Pastoralist in Kenya to Climate Change and Variability
}

\author{
Ayodotun Bobadoye *, William Ogara, Gilbert Ouma and Joshua Onono \\ 1 Institute for climate change and adaptation, University of Nairobi, Nairobi, Kenya; wogara@gmail.com \\ (W.O.); gouma@uonbi.ac.ke (G.O.); jshonono@gmail.com (J.O.) \\ * Correspondence: bobadoyed@gmail.com;
}

\begin{abstract}
Human adaptive responses to climate change occur at the local level, where climatic variability is experienced. Therefore analyzing vulnerability at the local level is important in planning effective adaptation options in a semi-arid environment. This study was conducted to assess vulnerability of Maasai pastoralist communities in Kajiado County, Kenya to climate change by generating vulnerability index for the communities. Data was collected using questionnaires that were administered to 305 households in the five different administrative wards (Oloosirkon/Sholinke, Kitengela, Kapetui North, Kenyawa-Poka and Ilmaroro) in Kajiado East. Vulnerability was measured as the net effect of adaptive capacity, sensitivity and exposure to climate change. Principal Component Analysis (PCA) was used to assign weights to the vulnerability indicators used for the study and also to calculate the household vulnerability index. A vulnerability map was produced using the GIS software package ArcGIS 10.2. Results showed that gender of household head, age of household head, educational level, access to extension agents, herd size, livestock diversity and access to credit facility influenced vulnerability of the Maasai pastoralists to climate change in Kajiado East. The result showed that the most vulnerable communities with the highest negative vulnerability index value are Ilpolosat (-2.31), Oloosirikon (-2.22), Lenihani (-2.05), Konza (-1.81) and Oloshaiki (-1.53). The communities with the highest positive vulnerability index values were Kekayaya (4.02), Kepiro (3.47), Omoyi (2.81), Esilanke (2.23), Kisaju (2.16) and Olmerui (2.15). We conclude that provision of basic amenities such as good roads and electricity; access to extension agents, access to credit facilities and herd mobility will reduce vulnerability of Maasai pastoralists in Kajiado east to climate change and variability
\end{abstract}

Keywords: vulnerability index, Maasai pastoralists, principal component analysis, climate change

\section{Introduction}

Many studies have been conducted on vulnerability to climate change and its extremes and different researchers have defined vulnerability according to their own perception. Adger (1999) defined vulnerability to climate change as "the extent to which a natural or social system is susceptible to sustaining the damage from climate change". IPCC (2014) defines vulnerability to climate change as "the degree of system susceptibility and its inability to cope with adverse effect of climate change and variability. Therefore vulnerability is a function of character, magnitude and rate of climate change and variability to which a system is exposed to. This also includes its sensitivity and adaptive capacity to climate change and variability".

The concept and definition of vulnerability that has been used by different studies revolves around the explanation of lack of adaptive capacity in both social and natural system. Climate change vulnerability has been studied by different scholars as a composite of adaptive capacity, sensitivity and exposure to hazard (Adger and Kelly 1999; Paavola 2008; Yuga et al., 2010; Deressa, 2010; Acheampong et al., 2014). Adaptive capacity can be defined as the ability to withstand or adjust to the changing context; it is the ability to implement adaptation measures that help avert potential impacts of climate change and variability (Opiyo, 2014; Acheampong et al., 2014). Sensitivity can be defined as the ability of a system to be affected by climate change and its extremes; it describes 
conditions that can trigger an impact or ameliorate hazard. Exposure is the nature and change in climate variables and extreme events; it is the physical impact of climate change such as change in rainfall pattern or rise in temperature range (Kasperson et al., 1995; Paavola 2008; Opiyo, 2014).

Climate change vulnerability can be analyzed from global level (IPCC 2014; Brooks 2004) to regional level (Deressa et al., 2009; Acheampong et al., 2014) and household level (Opiyo, 2014). The choice of vulnerability analysis scale depends on the aim of the research, available data and the methodology of the study. Most of the available scientific literatures on climate vulnerability analysis focus on national and regional vulnerability assessment usually for national or regional adaptation planning (Opiyo et al., 2014; Hinkel 2011). While vulnerability analysis at the national level is necessary for policy formulation and national planning; household vulnerability assessment conceptualizes how climate change and variability impacts directly on the household members and measures their ability to adapt. This is particularly useful for resource allocation and planning for adaptation strategies at the local level. Pearson et al., (2008) and Sherwood (2013) reported that vulnerability indices are diverse for the different multiple spatial scales and that household vulnerability assessment can be used to demonstrate how climate change affects livelihood of different communities. The aim of this study is to measure vulnerability of Maasai pastoralists' communities to climate change and to develop vulnerability maps showing the levels of vulnerability of Maasai pastoralist households to climate change and variability. This study will assist policy makers in resource allocation and climate adaptation planning in the arid and semi-arid lands of Kenya.

\section{Methodology}

\subsection{Study area}

The study was conducted in Kajiado East Sub-County (Figure 1). Kajiado East has a high population of Maasai tribe and Pastoralism is the main source of livelihood to a majority of households. The livestock breeds kept include sheep, goat, beef and dairy cattle and donkey. About $90 \%$ of the area is categorized as semi-arid eco-climatic zones and rainfall pattern is bimodal. The long rains season starts in March and this peaks in April and continues till May. The short rains begin in October and ends in December (Amwata, 2013; Bobadoye et al., 2014).

\subsection{Data collection}

Data were collected using semi-structured questionnaires administered to household heads in the five administrative wards in Kajiado East (Oloosirkon/Sholinke, Kitengela, Kapetui North, Kenyawa-Poka and Ilmaroro). A total of 305 household questionnaires were administered and 20 key informant interviews conducted between October 2014 and January 2015. Sample size was determined according to Krejcie and Morgan (1970) method of determining a sample size. Estimation of sample size in research using Krejcie and Morgan used the formula below to determine sample size:

$S=X^{2} N P(1-P) \div d^{2}(N-1)+X^{2} P(1-P)$

Where:

$\mathrm{S}=$ required sample size

$\mathrm{X}^{2}=$ the table value of chi-square for 1 degree of freedom at the desired confidence level (95\%) (3.841)

$\mathrm{N}=$ the population size

$\mathrm{P}=$ the population proportion (assumed to be .50 since this would provide the maximum sample size)

$\mathrm{d}=$ the degree of accuracy expressed as a proportion (.05).

Based on 1800 Maasai pastoralist households in Kajiado east, a total of 56 villages and 305 Maasai pastoralist household were sampled in this study 
The questionnaire used for the study was divided into the following: Household demographics, socio-economic characteristics, source of family income, livestock and crop production, basic amenities owned, size of land owned, access to extension service, access to credit facilities, perception to climate change, adaptation strategies, access to weather information and other relevant information.

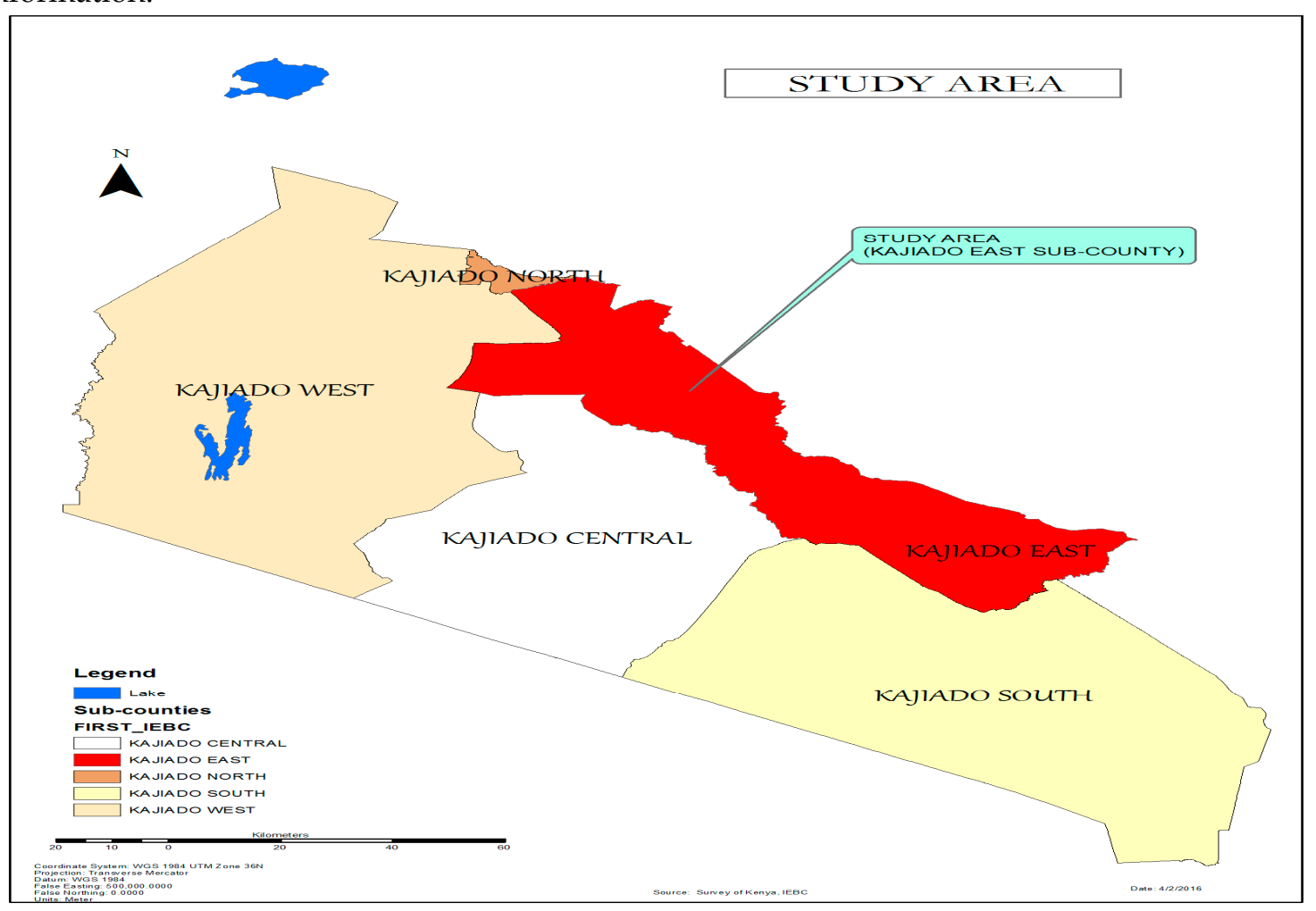

Figure 1: Map of the study area

\subsection{Vulnerability Analysis}

This study analyzed vulnerability of Maasai pastoralist as a net effect of adaptive capacity, exposure and sensitivity.

Vulnerability $=$ Adaptive capacity - (exposure + sensitivity $)$

The integrated vulnerability assessment method was used to analyze vulnerability of Maasai pastoralist to climate change. Vulnerability is a function of the character, magnitude and rate of climate variation to which a system is exposed, its sensitivity and its adaptive capacity". When adaptive capacity of the pastoralist household is less than the sensitivity and exposure, the household becomes more vulnerable to climate change impacts and the reverse is also true, the higher the adaptive capacity, the less vulnerable the household to climate change impact. This method uses a combination of indicators to measure vulnerability by computing indices and weighted average for the selected indicators. The indicators used in this study were selected based on researchers' observation, literature review of published research done in pastoralists' communities and the opinion of the Maasai pastoralist's communities in Kajiado County. Community involvement is important in selecting indicators for vulnerability analysis. This is because vulnerability to climate change is location specific.

The principal component analysis (PCA) was used to generate factor scores for calculating the vulnerability index for the households. In this study, the first principal component is the linear index of all the variables that captures the highest amount of information common to all variables.

The vulnerability index was determined based on three vulnerability components (adaptive capacity, exposure and sensitivity. Vulnerability index of household was calculated using the equation below:

$$
V_{i}=\left(A_{1} X_{1 j}+A_{2} X_{2 J}+\ldots \ldots \ldots+A_{n} X_{n j}\right)-\left(A_{1} Y_{1 j}+A_{2} Y_{2 j}+\right.
$$
$\left.\mathrm{A}_{\mathrm{n}} \mathrm{Y}_{\mathrm{nj}}\right)$ 
125
Where $\mathrm{V}_{\mathrm{i}=}$ vulnerability index
\[ \begin{array}{l}\mathrm{X}_{\mathrm{s}}=\text { indicators for adaptive capacity } \\ \mathrm{Y}_{\mathrm{s}}=\text { indicators for exposure and sensitivity } \\ \mathrm{A}_{\mathrm{s}}=\text { First component score of each variable computed using PCA. }\end{array} \]

The values of $X$ and $Y$ were obtained by normalizing the values of vulnerability indicators using their mean and standard deviations. In this study, Vulnerability index was calculated using 28 vulnerability indicators selected for adaptive capacity, exposure and sensitivity. Vulnerability index were generated for the 305 pastoralist household interviewed in 56 communities in Kajiado East (Table 1).

Table 1: Distribution of sampled villages in each ward

\begin{tabular}{|c|c|c|}
\hline Wards & $\begin{array}{l}\text { Villages sampled and number of questionnaires sampled per } \\
\text { village }\end{array}$ & $\begin{array}{l}\text { Total number of household } \\
\text { sampled per ward }\end{array}$ \\
\hline Kaputie North & $\begin{array}{l}\text { Emampariswai (4), Enkileele (3), Enkirgirri (3), Ilkiushin (3), Ilpolosat } \\
\text { (5), Isinya (8), Kekayaya (5), Kisaju, (8), Lenihani (3), Noosuyian (3), } \\
\text { Ntipilikuani (3), Olepolos (3), Olkinos (3), Olmerui (5), Oloshaiki (2), } \\
\text { Olturoto, (6), Ormoyi, (4). }\end{array}$ & 69 \\
\hline Kitengela & $\begin{array}{l}\text { Embakasi (8), Enkasiti (8), Kepiro (6), Kitengela (8), Korrompoi (7), } \\
\text { Mbuni (7), Nado Enterit (5), Naserian (8), Nkukuon (5), } \\
\text { Olooloitikoshi (5) }\end{array}$ & 67 \\
\hline Sholinke & $\begin{array}{l}\text { Embakasi (6), Enkutoto o mbaa (9), Kware (8), Nkukuon (6), } \\
\text { Olooloitikoshi (9), Oloosirikon (8), Sholinke (6) }\end{array}$ & 56 \\
\hline Kenyawa Poka & $\begin{array}{l}\text { Arroi (8), Esilanke (5), Kenyawa (6), Kibini (4), Mashuuru (5), } \\
\text { Noompaai, (6), Olgulului (5), Oltepesi (8), Poka (4), Sultan (5) }\end{array}$ & 55 \\
\hline Imaroro & $\begin{array}{l}\text { Arroi (4), Imaroro (4), Konza (6), Mbilin (6), Oibor Ajijik (4), } \\
\text { Olekaitoriori (10), Olgulului (8), Oloibor Ajijik (7), Oltepesi (7), Wulu } \\
\text { (8). }\end{array}$ & $57^{\prime}$ \\
\hline
\end{tabular}

The average vulnerability index for each community was determined by calculating the mean vulnerability index for the communities. The study presented the level of vulnerability of households and Maasai communities in the study area in a map. The vulnerability maps showing the levels of vulnerability of Maasai pastoralist communities (highly vulnerable, moderately vulnerable and less vulnerable) in the five administrative wards in the study area was produced using Geographical Information System (GIS) software package ArcGIS 10.2. Focus group discussions and key informant interviews with Maasai pastoralist and stakeholder meetings were conducted in the study area to verify and validate the vulnerability maps produced in this study.

The level of influence of the indicators on vulnerability of the households was also analyzed using the ordinal logistic regression model. The model is used when results are presented in ordinal scales, as in this study where vulnerability is categorized into (1) highly vulnerable (2) moderately vulnerable and (3) less vulnerable households.

The reduced form of ordinal logistic regression used in this study as described by Green (1997) is given as:

$$
Y_{j}^{*}=X_{j}^{i} \beta+\mathrm{U}_{\mathrm{ij}}
$$

Where $Y=$ Level of vulnerability and involves ordered vulnerability categories, $Y=1$ was given to highly vulnerable households, $Y=2$ was given to moderately vulnerable households and $Y=3$ was given to household less vulnerable households. $\mathrm{Y}^{*}$ is the given state of vulnerability. The $\mathrm{X}_{\mathrm{ij}}$ are the explanatory variables determining vulnerability level. $\beta_{\mathrm{s}}$ are parameters estimated and $\mathrm{U}_{\mathrm{ij}}$ is the disturbance term. 
157

158

159

160

161

162

163

164

165

166

167

168

169

170

171

172

173

174

175

176

177

\section{Results and Discussion}

\subsection{Vulnerability indicators and expected direction with respect to vulnerability}

The vulnerability indicators used for this study are presented in table 1 . The indicators were selected jointly by the researcher and the Maasai communities. These vulnerability indicators were categorized according to the definition of vulnerability as a function of adaptive capacity, exposure and sensitivity. In this study, the adaptive capacity is represented by wealth, infrastructure, access to information, literacy level and household size and the number of dependents. Wealth enhances the ability of communities to cope and recover from climate extremes. Size of herds, size of land owned and mobility of livestock are indicators used by Maasai pastoralist to assess the level of wealth of pastoralist households (Opiyo et al., 2014). O O' Brien et al. (2004) reported that availability of basic infrastructures plays an important role in adaptation to climate change. It increases the ability of rural dwellers to diversify their sources of income thereby enhancing their adaptive capacity. Likewise, availability of hospitals can enhance the provision of preventive treatments for diseases associated with climate change such as malaria and meningitis.

In this study, sensitivity is represented by level of education, household size, gender and age of household head. It is believed that the level of education of the household head impact on the sensitivity of the household to climate variability and change. It has also been reported that households with smaller size are more likely to withstand climate change and its extreme (Opiyo, 2014). Exposure in this study is represented by the frequency of extreme climatic events such as droughts and floods and also by change in temperature and precipitation amount. 
Table 1: Vulnerability indicators and expected direction with respect to vulnerability

\begin{tabular}{|c|c|c|c|}
\hline $\begin{array}{l}\text { Determinants of } \\
\text { Vulnerability }\end{array}$ & $\begin{array}{l}\text { Vulnerability } \\
\text { indicators }\end{array}$ & $\begin{array}{l}\text { Description of indicator } \\
\text { used for analysis }\end{array}$ & $\begin{array}{l}\text { Relationship between indicator and } \\
\text { vulnerability }\end{array}$ \\
\hline \multirow[t]{3}{*}{ Adaptive capacity } & Wealth & $\begin{array}{l}\text { Herd size, livestock } \\
\text { diversity, land size, non- } \\
\text { farm income, crop farming } \\
\text { income }\end{array}$ & $\begin{array}{l}\text { The more the size of land own and } \\
\text { income generated by households the } \\
\text { less the vulnerability to climate } \\
\text { change }\end{array}$ \\
\hline & Access to information & $\begin{array}{l}\text { Visit by extension agents, } \\
\text { access to climate } \\
\text { information }\end{array}$ & $\begin{array}{l}\text { The more access the household has } \\
\text { to climate information the less their } \\
\text { vulnerability }\end{array}$ \\
\hline & $\begin{array}{l}\text { Infrastructures and } \\
\text { asset }\end{array}$ & $\begin{array}{l}\text { Access to electricity, toilet } \\
\text { and hospitals. Own radio } \\
\text { and TV }\end{array}$ & $\begin{array}{l}\text { The more the households that have } \\
\text { access to electricity, hospitals and } \\
\text { other asset the less their vulnerability }\end{array}$ \\
\hline \multirow[t]{2}{*}{ Sensitivity } & $\begin{array}{l}\text { Household } \\
\text { characteristics }\end{array}$ & $\begin{array}{l}\text { Household size, number of } \\
\text { dependent, marital status, } \\
\text { gender of household head, } \\
\text { age of household head }\end{array}$ & $\begin{array}{l}\text { The higher household size and } \\
\text { number of dependent, the higher the } \\
\text { vulnerability. Female headed } \\
\text { households are more vulnerable }\end{array}$ \\
\hline & Literacy level & Level of education & $\begin{array}{l}\text { The higher the literacy rate, the less } \\
\text { the vulnerability }\end{array}$ \\
\hline \multirow[t]{2}{*}{ Exposure } & Extreme climates & $\begin{array}{l}\text { Frequency of drought and } \\
\text { floods }\end{array}$ & $\begin{array}{l}\text { The higher the frequency of extreme } \\
\text { events the more the vulnerability }\end{array}$ \\
\hline & Change in climate & $\begin{array}{l}\text { Temperature change } \\
\text { Precipitation change }\end{array}$ & $\begin{array}{l}\text { Reduced rainfall and increase } \\
\text { temperature increase vulnerability }\end{array}$ \\
\hline
\end{tabular}


Table 2 . show that only $8.5 \%$ of the households were headed by females and these confirms the findings of Omolo (2010) that Maasai communities are patriarchal and women are less involved in decision making, and are often relegated to taking care of the children and other household activities. This is expected to reduce the female headed household early access to climatic information and early warning information and affect their ability to respond early to extreme climatic events. Data on household size shows that $91.5 \%$ of respondents had household size of more than Five (5) people. Results showed that $33 \%$ of the household heads had no formal education and level of education affect the ability of pastoralist to adapt to climate change. Lack of formal education affects the ability of the household to understand and interpret climate information for decision making (Opiyo et al., 2014). Various findings (Yohe and Tol 2002; Skjeflo 2013; Opiyo 2014) has shown that household size has a significant influence on the vulnerability of the households to climate change and climate extremes.

Smaller households are usually less susceptible to climate extreme events such as drought. This is because food scarcity is one of the main challenges during drought and the lesser the household size, the easier it is to cope with scarcity of food. The results also showed that other adaptive capacity indiators such as marital status, access to extension agents, herd size, livestock diversity and access to credit facilities positively influenced vulnerability in the study area. This result concur with the findings of Katoka et al., (2011) and Opiyo et al., (2014) which similarly reported that most of these variables affects household vulnerability to climate change in the pastoralist communities. 
Table 2: Indicators and their effects on vulnerability

\begin{tabular}{|c|c|c|}
\hline Hypothesized variables & Percentage of household & Influence on vulnerability \\
\hline \multicolumn{3}{|l|}{ Sensitivity Indicators } \\
\hline Gender of HH head: female headed households & 8.5 & + \\
\hline Age of $\mathrm{HH}$ head: $50+$ years & 64.9 & + \\
\hline Experience in the area: $45+$ years & 56.4 & - \\
\hline HH size: $5+$ persons & 91.5 & + \\
\hline Education level: no primary education & 33.0 & + \\
\hline Dependents: $5+$ persons & 9.6 & - \\
\hline Marital status: single (including divorced and widowed) & 10.6 & + \\
\hline Visit by extension officers: no access to extension services & 83.0 & + \\
\hline Receive climate information & 90.0 & - \\
\hline \multicolumn{3}{|l|}{ Adaptive capacity Indicators } \\
\hline Crop-farming income: with income from crop farming & 7.4 & - \\
\hline Non-farm income: with income from non-farm activities & 74.5 & - \\
\hline Herd size: $100+$ total herd size & 85.1 & - \\
\hline Livestock diversity: own 2+ domestic animal types & 93.4 & - \\
\hline Land size: own $100+$ acres & 57.4 & - \\
\hline HH members employed: $3+$ members employed & 36.2 & - \\
\hline Credit access: have no access to credit & 72.3 & + \\
\hline Livestock mobility: able to move livestock freely & 62.8 & - \\
\hline Own radio & $94 \%$ & - \\
\hline Own TV & $68 \%$ & - \\
\hline Access to electricity & $22 \%$ & - \\
\hline Access to hospital & $94 \%$ & - \\
\hline Access to toilet & $72 \%$ & - \\
\hline \multicolumn{3}{|l|}{ Exposure Indicators } \\
\hline Temperature: noticed increase & 93.6 & + \\
\hline Rainfall: noticed decrease & 90.0 & + \\
\hline Drought: experience drought within the last 10 years & 100.0 & + \\
\hline Floods: experience floods within last the 10 years & 74.5 & + \\
\hline Drought frequency: every year & 47.9 & + \\
\hline Floods frequency: every year & 2.1 & - \\
\hline
\end{tabular}

Positive sign means indiators increase vulnerability while negative sign means they

\subsection{Vulnerability Analysis of Maasai pastoralist to climate change in Kajiado County}

Table 3 shows the result of the factor score for the first principal component analysis and its association with the vulnerability variables. Principal Component Analysis was run on the indicators listed in Table 1 to generate the factor scores. The first principal component was used to generate the factor scores (weight) because it explains $91 \%$ of the variations. Vulnerability index was computed based on the definition of vulnerability in equation (2) which defines vulnerability as a net effect of adaptive capacity minus exposure and sensitivity. The indicators of adaptive capacity which were positively associated with the first principal component analysis and the indicator of sensitivity and exposure, which were negatives associated with the first principal component analysis were used to calculate the vulnerability index in the study. This is because the vulnerability equations shows that increase in adaptive capacity contributes to reduction in vulnerability, while increase in exposure and sensitivity increases vulnerability. The variables with higher factor scores have higher influence on vulnerability in the study area. The vulnerability of households in the study area was classified based on the different communities in the study area using the vulnerability index.

The result of vulnerability index of communities in Kajiado east is presented in table 4 . This study calculated vulnerability index for 305 households in 56 Maasai communities in the five administrative wards in Kajiado east sub-County. The vulnerability index of the communities was determined by calculating the average vulnerability index for households in each community. The 
results shows that Ilpolosat, Oloosirikon, Lenihani, Konza and Oloshaiki were the most vulnerable communities having the highest negative vulnerability index value of $-2.31,-2.22,02.05,-1.81$ and 1.53 respectively. The least vulnerable communities with the highest positive vulnerability index values were Kekayaya, Kepiro, Omoyi, Esilanke, Kisaju and Olmerui with values of 4.02, 3.47, 2.81, $2.23,2.16$ and 2.15 respectively. The vulnerability index of communities varied between 4.02 to -2.31 . The result shows high disparity in the vulnerability of communities in Kajido east. It concur with the findings of Orindi et al., (2007) which reported that land sub division and sales among the Maasai in Kajiado has increased the standard of living of few Maasai while most are left highly vulnerable and unable to practices their pastoralist system. Increase in dry spell and drought over the last few decades coupled with restriction in animal movement have also increased vulnerability of Maasai pastoralist to climate change and variability ( Kakota et al., 2011; Opiyo et al., 2014).

Table 3: Factor scores for the first principal component analysis

\begin{tabular}{ll}
\hline Factors & Factor \\
\hline Social vulnerability variables & Scores \\
\hline Gender House Hold head & 0.02 \\
Age of HH head: 50+ years & -0.0138 \\
Experience in the area: $45+$ years & 0.0158 \\
HH size: 5+ persons & -0.051 \\
Education level: no primary education & -0.13 \\
Visit by extension workers: no access to extension services & -0.01 \\
Receive climate information & 0.001 \\
Dependents: 5+ persons & -0.06 \\
Marital status of HH head: single (including divorced and widowed) & 0.04 \\
Own radio & 0.0000 \\
Own television & 0.4 \\
Own mobile phone & 0.3 \\
Access to electricity & 0.2 \\
Toilet & 0.19 \\
Access to a hospital & 0.003 \\
\hline Economic vulnerability variables & \\
Crop farming income: with income from crop farming & 0.19 \\
Non-farm income: with income from non-farming activities & 0.04 \\
Herd size: 100+ total herd size & 0.286 \\
Livestock diversity: own 2+ domestic animal types & 0.22 \\
HH members employed: 3+ members employed & 0.030 \\
Credit access: have no credit access & 0.002 \\
Livestock mobility: able to move livestock freely & 0.15 \\
Land size: own 100+ acres & 0.90 \\
\hline Environmental vulnerability variables & \\
Rainfall: noticed decrease & -0.02 \\
Temperature: noticed increase & -0.12 \\
Drought: experienced drought within the last 10 years & -0.22 \\
Floods: experienced floods within the last 10 years & 0.0001 \\
Drought frequency: every year & 0.0004 \\
Floods frequency: every year &
\end{tabular}


Table 4: Vulnerability index of Maasai communities in Kajiado east sub-County

\begin{tabular}{|c|c|c|c|c|c|c|c|}
\hline Villages & $\begin{array}{l}\text { Vulnerabilit } \\
\text { y index }\end{array}$ & X Coordinate & Y Coordinate & Villages & $\begin{array}{l}\text { Vulnerability } \\
\text { index }\end{array}$ & X Coordinate & Y Coordinate \\
\hline Kisaju & 2.16 & 36.82 & -1.6 & Wulu & 0.87 & 37.14 & -1.81 \\
\hline Isinya & -0.37 & 36.84 & -1.69 & Esilanke & 2.23 & 36.76 & -1.72 \\
\hline Olmerui & 2.15 & 36.88 & -1.75 & Olgulului & 1.02 & 37.30 & -2.23 \\
\hline Poka & -0.31 & 37.45 & -2.13 & Noompai & -1.15 & 37.46 & -2.34 \\
\hline Sultan & -0.21 & 37.37 & -2.02 & Kekayaya & 4.02 & 37.46 & -1.59 \\
\hline Kitengela & 0.36 & 36.96 & -1.47 & Lenihani & -2.05 & 37.06 & -1.69 \\
\hline Konza & -1.81 & 37.13 & -1.74 & Embakasi & 0.057 & 36.83 & -1.39 \\
\hline Mashuru & 0.73 & 37.13 & -2.10 & Kware & -0.11 & 36.81 & -1.46 \\
\hline Oletepes & 0 & 36.77 & -1.47 & Enkutoto mbaa & 0.02 & 36.74 & -1.43 \\
\hline Olooloitikoshi & 0.48 & 36.80 & -1.57 & Kepiro & 3.47 & 36.85 & -1.64 \\
\hline Oloosirikon & -2.22 & 36.81 & -1.43 & Korrompoi & -0.37 & 36.92 & -1.62 \\
\hline Sholinke & -0.19 & 36.78 & -1.51 & Olturoto & -1.51 & 36.90 & -1.64 \\
\hline Iltepes & 0.23 & 37.23 & -2.19 & Naserian & 0.43 & 36.97 & -1.66 \\
\hline Kenyawa & 1.44 & 37.58 & -2.19 & Emampariswai & 0.49 & 36.98 & -1.70 \\
\hline Kibini & 0.44 & 37.29 & -2.13 & Ntipilikuani & 0.02 & 36.67 & -1.69 \\
\hline Arroi & 0.08 & 37.30 & -2.02 & Olepolos & 1.54 & 36.70 & -1.51 \\
\hline Imaroro & -1.33 & 37.09 & -1.95 & Oloshaiki & -1.53 & 36.95 & -1.56 \\
\hline Mbilini & 1.68 & 37.05 & -1.97 & Ormoyi & 2.81 & 36.73 & -1.65 \\
\hline llkuishin & -0.31 & 36.94 & -1.75 & Enkasiti & -0.14 & 36.87 & -1.57 \\
\hline Enkirigirri & 0.30 & 36.85 & -1.78 & Mbuni & -0.44 & 36.87 & -1.55 \\
\hline Ilpolosat & -2.31 & 37.06 & -1.75 & Oloibor Ajijik & 0.74 & 37.06 & -1.89 \\
\hline Olkinos & -1.15 & 36.88 & -1.66 & & & & \\
\hline Olekiatorio & 0.31 & 37.17 & -1.20 & & & & \\
\hline
\end{tabular}

\subsection{Vulnerability maps of households and communities in Kajiado East sub County}

Maps have the advantage of presenting data in an easily assessable, readily visible and eye catching manner. Mapping vulnerabilities to climate change is a key planning tool for government and policy makers in resources allocation and adaptation planning. There is the urgent need in Kenya for availability of information especially at the local levels where intervention are needed for establishing early warning systems, disaster risk response and capacity building. 


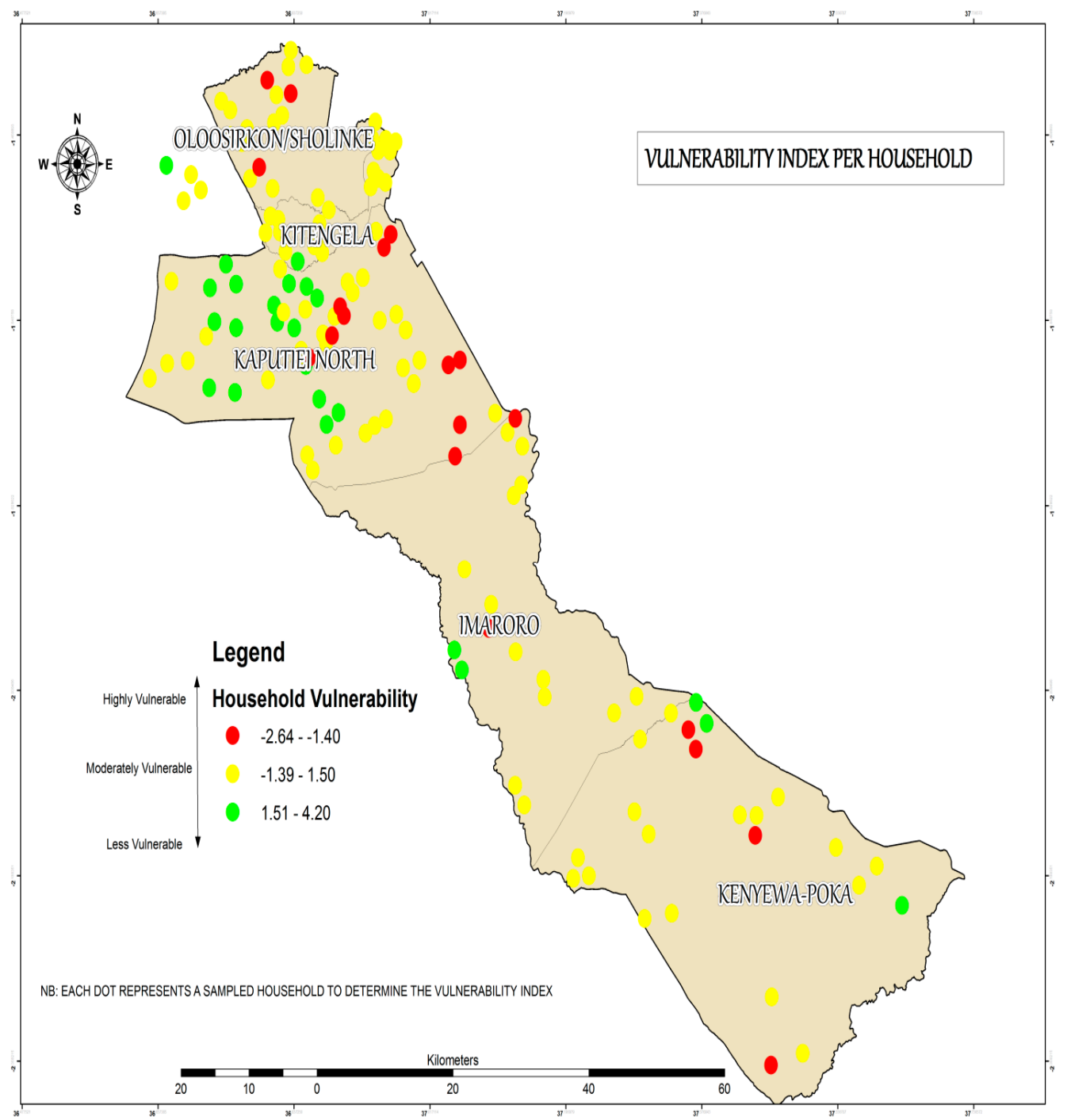

Figure 2: Map showing the level of vulnerability of households in Kajiado East to climate change and variability

Figure 2 shows the vulnerability map of households in Kajiado east sub-County. The map shows that households in most communities in Kajiado east are moderately vulnerable to climate change and variability. The map also revealed a high level of variation in the vulnerability of some households within the same community. This shows that although communities are exposed to the same climatic factors, the adaptive capacity of the household has a significant effect on its vulnerability. Fussel (2007) and Deressa (2010) reported that individual households within the community vary in socio-economic characteristics such as level of education, wealth, access to credit and political power; which are responsible for variation in vulnerability levels. Mapping household vulnerability is important in identifying vulnerable household within a community and also understanding vulnerability pattern of household in the community. However, mapping vulnerability at the community level provides information for policy makers and decision makers to take informed decisions that will enhance resilience of vulnerable communities.

Figure 3 shows the vulnerability map of communities in Kajiado east. The map categorized communities into highly vulnerable, moderately vulnerable and vulnerable communities based on their vulnerability index. The maps revealed that although most communities in Kaputie North ward are moderately vulnerable; Maasai communities in Iloposat, Lenihani, Oloshaiki and Olturoto are highly vulnerable to climate change and variation. Kitengela ward has the highest number of Maasai communities that are less vulnerable; this might be due to the availability of basic amenities such as good roads, electricity and hospitals. Maasai communities that are highly vulnerable to climate 
change and variability in Sholinke ward are communities living in Oloosirikon and Korrompoi. The other Maasai communities in Sholinke are moderately vulnerable to climate change and variability. The map shows that communities in Mbilin and Koonza of Imaroro ward are also highly vulnerable to climate change and variability. In Kenyawa-Poka ward, most communities are moderately vulnerable to climate change and variability, however, the map shows that communities in Noompai are highly vulnerable while those in Esilanke are less vulnerable to climate change and variability.

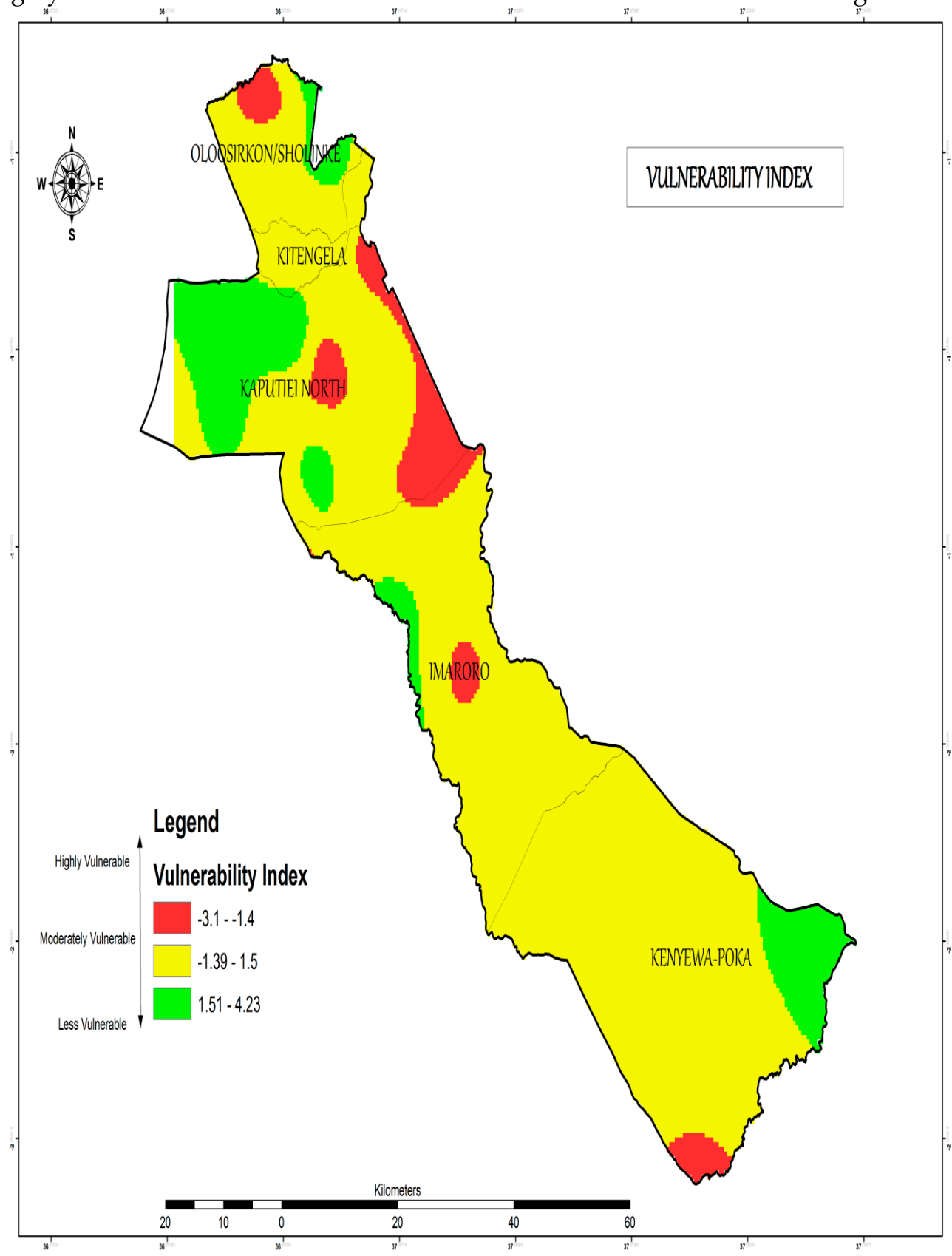

Figure 3: Map showing the level of vulnerability of communities in Kajiado East to climate change and variability

The maps further revealed that Kaputiei North sub county has the highest number of highly vulnerable households, followed by Oloosirkron/Shilonke, Imaroro and Kitengela has almost the same number of household that are highly vulnerable while Kenyawa-Poka has the least number of households that are highly vulnerable. The household that are highly vulnerable are unable to cope with the adverse effect of climate change and variability and needs immediate external assistance in terms of relief to survive. Previous studies in ASALs of Kenya (Orindi et al., 2007; Omolo 2010; Amwata, 2013) reported that it is becoming difficult for households to recover from changing and 
inconsistent weather conditions affecting the pastoralist livelihood. The result is also consistent with the findings of Opiyo et al., (2014); and Ongora and Ogara (2012) conducted in similar ecosystem in Kenya.

Findings from this study shows an urgent need for evidence based policies and plans to improve the adaptive capacity of Maasai pastoralist through provision of basic amenities and also well structured early warning and disaster response systems to reduce their vulnerability to climate change and variability.

\subsection{Variables influencing household vulnerability in the study area}

The result of the ordered logistic regression model for the variables influencing the vulnerability of household is presented in table 4 . A total of nine variables have significant influence (at $5 \%$ and $10 \%$ levels of significance) on vulnerability to climate change in the study area. The result shows that gender of household head, years of experience in the area, educational level, visit by extension agents, herd size, livestock diversity, land size and livestock mobility has significant influence on vulnerability in the study area.

The Maasai communities are typically patriarchal and female headed households, households that access to extension agents and those with low level of education are significantly vulnerable to climate change. This is because such households either lack access to information for early decision making during extreme climatic events or lack the economic capacity to act on decisions during extreme conditions.

Table 4: Variables influencing household vulnerability to climate change and variability

\begin{tabular}{|c|c|c|c|c|c|}
\hline Variables & Estimates & SE & OR & $\mathrm{Z}$ & P-value \\
\hline Gender of $\mathrm{HH}$ head: female headed $\mathrm{HH}$ & 1.9585 & 0.5522 & 5.34 & 3.561 & $0.02910^{*}$ \\
\hline Age of HH head: 50+years & 0.02838 & 0.95623 & 0.083 & 0.029 & 0.76657 \\
\hline Experience in the area: $45+$ years & 0.48827 & 0.039463 & 1.409 & 12.237 & $0.06598^{* *}$ \\
\hline HH size: 5 persons and above & 0.02110 & 0.369333 & 0.051 & 0.057 & 0.95443 \\
\hline Educational level: no primary education & 0.75148 & 0.650586 & 2.175 & 1.269 & $0.07776^{* *}$ \\
\hline Dependents:5+persons & -0.12651 & 0.137281 & 0.372 & -0.922 & 0.35676 \\
\hline Marital status: Single (including divorced and widowed & -0.811681 & 0.951857 & 2.312 & -0.853 & $0.09381^{* *}$ \\
\hline Visit by extension officers: no access to extension services & -1.50143 & 0.475808 & 4.501 & -1.217 & $0.0898^{* *}$ \\
\hline Receive climate information & 1.0987 & 0.876 & 4.439 & 1.6323 & 0.6721 \\
\hline Crop-farming income: with income from crop farming & 0.803874 & 1.540628 & 2.804 & 0.522 & 0.60182 \\
\hline Non-farm income: with income from non-farm activities & 0.14548 & 1.303264 & 0.335 & 0.112 & 0.91111 \\
\hline Herd size: $100+$ total herd size & 0.018564 & 0.006389 & 0.049 & 2.906 & $0.00366^{*}$ \\
\hline Livestock diversity: own $2+$ domestic animal types & 0.5345 & 0.662073 & 1.535 & 1.807 & $0.08194^{* *}$ \\
\hline Land size: own 100+ acres & 0.00847 & 0.002773 & 0.018 & 3.055 & $0.00225^{*}$ \\
\hline HH members employed: $3+$ members employed & -0.18518 & 0.40269 & 0.385 & -0.46 & 0.64561 \\
\hline Credit access: have no access to credit & -0.95355 & 0.251682 & 2.954 & -0.962 & 0.74617 \\
\hline Livestock mobility: able to move livestock freely & 0.933049 & 0.203249 & 2.903 & 4.775 & $0.08380^{* *}$ \\
\hline Temperature: noticed increase & -0.84119 & 1.821335 & -2417 & -0.462 & 0.64418 \\
\hline Rainfall: noticed decrease & -0.04989 & 0.67590 & 0.123 & -0.432 & 0.8765 \\
\hline Drought: experience drought within the last 10 years & -0.34234 & 0.8650 & 1.4971 & -0.32967 & 0.71607 \\
\hline Floods: experience floods within last the 10 years & -0.012425 & 3.215686 & 0.042 & -0.004 & 0.99692 \\
\hline Drought frequency: every year & -0.291552 & 0.751606 & 1.292 & -0.388 & 0.69809 \\
\hline Floods frequency: every year & -1.53658 & 0.664387 & 2.154 & -2.318 & 0.8171 \\
\hline
\end{tabular}

$\mathrm{SE}=$ standard error, $\mathrm{OR}=$ odd ratio, $\mathrm{z}$ is score of two sample test. The statistical significant of the p value was expressed at $5 \%^{*}$, and $10 \%{ }^{* *}$

Several studies (Kakota et al., 2011; Tesso et al., 2012; Opiyo 2014) conducted in pastoral communities in Eastern Africa reported that female headed household are usually not empowered enough to take decisions during extreme climatic events such as drought and are frequently without access to credit services and adequate capital assets. They are also not able to own large herds to manage household's daily requirements. This shows the need to specifically target pastoralist women 
in climate change adaptation planning in arid and semi-arid lands of Kenya. This study also concurs with Blench (2000) which reported the significant influence of level of education on vulnerability in similar ecosystem.

The significant influence of herd size, livestock diversity, access to credit, land size and livestock mobility is also reported in this study. These factors enhance the ability of households to cope during extreme climatic events and reduce their vulnerability to climate change and its extremes. This agrees with studies by Eriksen et al. (2005) and Notenbaert et al. (2013) who also reported some of these factors as key determinant of household vulnerability to climate variability and change in rural communities. The result is also consistent with previous studies by Kakota et al. (2011) and Opiyo (2014) conducted in similar ecosystem.

\section{Conclusion}

This study used indicators developed jointly by the researcher and the Maasai communities to analyze household vulnerability of Maasai communities in Kajiado east. Categorization of vulnerability levels using maps is useful for government both at the National and County level for efficient resource allocation to the wards. Human adaptive response to climate change occurs at the local and household level where the climate variability is experienced. It is therefore crucial to understand vulnerability at the household level for timely intervention and also for development of evidence based policies that will lead to effective adaptation programmes for long term resilience.

The vulnerability map shows that households in Kitengela ward which is the most developed ward in terms of access to basic amenities is the least vulnerable ward in Kajiado East. Result also shows that indicators such as gender of household head, level of education, access to credit facilities, access to extension services and herd's mobility significantly affects vulnerability of Maasai pastoralist to climate change and its effect. It is therefore necessary for government at all levels to develop policies and programmes that will address the huge infrastructural deficit in Kajiado county, as this will not only reduce vulnerability to climate extremes, it will also reduce the huge poverty level which currently stands at about $50 \%$ (GOK, 2013).

The study concludes that there is disparity in the vulnerability levels of households within communities and also among wards in Kajiado east. Resilience intervention should therefore be specific, targeting wards within the Counties and also particular households within the communities. Interventions such as women empowerment, access to extension agents, provision of basic infrastructures such as electricity, water, and good roads, free herd mobility and access to credit facilities will increase resilience of Maasai pastoralist in Kajiado East to the effect of climate change and variability.

\section{Acknowledgments:}

Author Contributions:

\section{Conflicts of Interest:}

\section{References}

1. Acheampong, E.N., Ozor, N. and Owusu, E.S. (2014). Vulnerability assessment of Northern Ghanato climate variability. Climate Change (2014) 126:31-44 DOI10.1007/s10584-014-1195-z.

2. Adger, W.N. (1999). Social vulnerability to climate change and extremes in Coastal Vietnam. World Development. 27(2): 249-269.

3. Adger, W.N. and Kelly, P.M. (1999). Social vulnerability to climate change and architecture of entitlements. Mitigation and adaptation strategies for Global change 4: 253-266.

4. Amwata, D.A. (2013). The influence of climate variability and change on Land-use and Livelihoods in Kenya's Southern rangelands. A PhD thesis submitted to the Department of Land Resource Management and Agricultural Technology, University of Nairobi.

5. Bobadoye, A.O., Ogara W.O., Ouma, G.O. and Onono, J.O. (2014). Comparative analysis of rainfall trends in different Sub Counties in Kajiado County Kenya. IJIRS. Vol.3 Issue12. ISSN 2319-9725.

6. Blench, R. (2000). Extensive pastoral livestock systems: Issues and options for the future. 
7. Brooks, N. (2004). Drought in the African Sahel: long-term perspectives and future prospects. Working Paper 61, Tyndall Centre for Climate Change Research, University of East Anglia, Norwich, 31 pp

8. Deressa, T., Hassan, R.M. and Ringler, C. (2009). Measuring Ethiopian farmers' vulnerability to climate change across regional states. IFPRI discussion paper no. 806

9. Deressa, T.T. (2010). Assessment of the vulnerability of Ethiopian agriculture to climate change and farmers' adaptation strategies. A PhD thesis submitted to the Department of Agricultural Economics, Extension and Rural Development, University of Pretoria

10. Eriksen, S. H., Brown, K. and Kelly, P.M. (2005). The Dynamics of Vulnerability: Locating Coping Strategies in Kenya and Tanzania. The Geographical Journal 171(4): 287-305.

11. Fussel, H. (2007). Vulnerability: a generally applicable conceptual framework for climate change research. Global Environmental Change 17:155-167

12. GOK (2013), Government of Kenya. County Government of Kajiado, County Integrated Development Plan 2013-2017.

13. Hinkel, J. (2011). Indicators of vulnerability and adaptive capacity: towards a clarification of the sciencepolicy interface. Global Environmental Change 21: 198-208.

14. IPCC (2014). Climate change 2014. Impacts, Adaptation and Vulnerability. Contribution of working group II to the Fifth Assessment Report of the Intergovernmental panel on climate change.

15. Intergovernmental Panel on Climate Change IPCC. (2012). Managing the risks of extreme events and disasters to advance climate change adaptation. A special report of Working Groups I and II of the Intergovernmental Panel on Climate Change. Cambridge, United Kingdom and New York, USA: Cambridge University Press. 582p.

16. Katoka, T., Nyariki, D., Mkwabisi, D and Kogi-Makua, W. (2011). Gender vulnerability to climate variability and household food insecurity. Climate and Development 3(4): 298-309

17. Kasperson, J., Kasperson, R. and Turner, B. (eds). (1995). Regions at risk: Comparisons of Threatened Environments. New York: United Nations University Press

18. Krejcie, R. V. and Morgan, D. W. (1970). Determining sample size for research activities. Educational and Psychological Measurement, 30, 607-610.

19. O’Brien, K., Leichenko, R., Kelkar, U, Venema, H., Aandahl, G., Tompkins H., Javed, A., Bhadwal, S., Barg, S., Nygaard, L. and West, J. (2004). Mapping vulnerability to multiple stressors: climate change and globalization in India. Glob Environ change 14:303-313.

20. Omolo, N. A (2010). "Gender and climate change induced conflict in pastoral communities: Case study of Turkana in Northwestern Kenya". In: African Journal of Conflict Resolution, 102:81-102.

21. Ongoro, E.B and Ogara, W. (2012). Impact of climate change and gender roles in community adaptation: A case study of pastoralist in Samburu East District, Kenya. International Journal of Biodiversity and Conservation Vol. 4(2), Pp. 78-89.

22. Opiyo E.O., Wasonga, V.O. and Nyangito, M.M. (2014). Measuring household vulnerability to climateinduced stresses in pastoral rangelands in Kenya: Implication for resilience programming. Pastoralism: Research, Policy and Practice 2014, 4:10

23. Opiyo, E. O. (2014). Climate variability and change on vulnerability and adaptation among turukana pastoralist in north-western Kenya. A PhD thesis submitted to the Department of Rangeland management, University of Nairobi.

24. Orindi, V.A., Nyong, A. and Herrero, M. (2008). Pastoral Livelihood Adaptation to Drought and Institutional Intervention in Kenya. Human Development Report 2007/2008.

25. Pearson, L., Nelson, R., Crimps, S. and Langridge, J. (2008). Climate change vulnerability assessment: Review of agricultural productivity, CSIRO climate adaptation flagship working paper 08.1.

26. Paavola, J.(2008). Livelihoods, vulnerability and adaptation to climate change in Morogoro, Tanzania. Environmental Science and Policy 11(7): 642-654.

27. Sherwood, A. (2013). Community adaptation to climate change: exploring drought and poverty in Gituamba location, Kenya. Journal of National Resources Policy Research 5(2-3): 147-161.

28. Tesso, G., Emana, B. and Ketema, M. (2012). Analysis of vulnerability and resilience to climate change induced shocks in North Shewa, Ethiopia. Agricultural Sciences 3: 871-888.

29. Yuga, N.G., Shivatoki, P.G. and Sylvian, R.P. (2010). Household level vulnerability to drought in hill agriculture of Nepal: Implications for adaptation planning. International Journal of Sustainable Development and World Ecology. 17(3):225-230. 